\title{
State of the art on clinical trials of gene therapy in haemophilia
}

\author{
I. Garagiola ${ }^{1}$, F. Peyvandi ${ }^{1,2}$ \\ ${ }^{1}$ Fondazione IRCCS Ca' Granda, Ospedale Maggiore Policlinico, Angelo Bianchi Bonomi Hemophilia and \\ Thrombosis Center, Fondazione Luigi Villa, Milan, Italy \\ 2Università degli Studi di Milano, Department of Pathophysiology and Transplantation, Milan, Italy \\ E-mail: flora.peyvandi@unimi.it
}

\section{Summary}

Haemophilia A and B are rare inherited bleeding disorders, caused by deficiency or dysfunction .of the coagulation factors(F) VIII (haemophilia A) or IX (haemophilia B) which have an essential role in the coagulation cascade. These dysfunctions cause a defect in clot formation and consequent bleeding diathesis. The main therapeutic strategy is the venous infusion of either plasma-derived or recombinant products. Treatment is given in response to an acute bleeding episode (on-demand) or as prophylaxis by infusion 2-3 times per week to prevent haemorrhages.

Nowadays, the introduction of new extended half-life products has transformed the concept of haemophilia replacement therapy by reducing the frequency of injections, achieving a higher trough level and improving patients' quality of life. Furthermore, a substantial change has happened with the availability of the bispecific antibody. Haemophilia A patients with and without inhibitors can be subcutaneously treated reducing significantly the interval between injections once a week or every two weeks.

In the last few years, clinical trials in both haemophilia A and B hve shown efficacy and durability of transgene expression. Phase $1 / 2$ studies have shown that a single intravenous infusion allows to reach a normal level in patients with haemophilia A and B. Long-term follow-up for gene therapy in haemophilia B showed that the infusion of a single dose of vector resulted in a therapeutic FIX activity level after 10 years. These levels of FVIII and FIX expression allow to patients to leave the prophylactic regimen and to reduce the bleeding events to zero.

This article mentions the state of the art of gene therapy studies for haemophilia A and B, including data on efficacy and any side effects observed until now.

\section{Introduction}

Gene therapy has been one of the greatest biotechnological success stories of the 21st century. The first approved gene therapy procedure was performed in a patient with a rare genetic disease, adenosine deaminase deficiency (ADA), in 1995 (1). Nowadays, gene therapy is a promising medication applicable to a broad number of diseases, with nearly 400 clinical trials currently underway for the first quarter of 2019. Haemophilia is an ideal target for gene therapy being a monogenic disorder and in addition, a modest increase in clotting factor activity (1 IU/dL) can reduce clinical symptoms and can be easily measured by routine laboratory testing. (2).

Gene therapy consists of effective strategies that involve the administration of genes in vivo directly 
into the target cells or tissues of patients or ex vivo delivery of the gene into autologous cells followed by a transfer in the patient (3). After the first successes, progress was slowed down due to serious adverse events in patients treated with gene therapy. The first 'biotech death', as defined in the 1999 by The New York Time Magazine, occurred in a young patient enrolled in a clinical gene therapy trial for ornithine transcarbamylase deficiency (OTC). The immune system of patient responded immediately after administration of adenovirus at very high doses and died four days later due to multi-organ failure (4). At the beginning of the 2000's another serious adverse event occurred in patients treated for severe combined immunodeficiency (SCID) by ex vivo gene delivery: the occurrence of vector-related leukaemia $(5,6)$. Consequently, all gene therapy trials had been halted, and over the following decade, the research community worked on improving the safety, capacity, and efficacy of the viral vectors (6).

The first gene therapy experience in haemophilia was conducted with an ex vivo gene transfer. Two patients with haemophilia B has been treated in 1996 using retroviral vector administration in autologous skin fibroblasts (7). This experience resulted to be safe, but the transgene expression was not long lasting and lost the expression after 420 days.

Subsequently, there have been considerable improvements to manufacture novel vectors to obtain substantial expression levels and long-term duration while improving safety levels.

An efficient gene transfer in animal models with haemophilia was achieved using adeno-associated virus (AAV). Therapeutic levels of functional FVIII and FIX in a dose-dependent manner were obtained $(8-15)$. AAV is a non-enveloped parvovirus that can be arranged to deliver DNA to target cells and has attracted interest especially in clinical-stage experimental treatment strategies. AAV is a defective virus that requires a helper virus for an active infection, otherwise it can establish a latent infection through integration into host genome or maintenance as a circular episomal form (16). The ability to generate recombinant AAV particles without any viral genes and containing DNA sequences of interest for various therapeutic applications has thus far proven to be one of the most commonly used strategies in gene therapy.

AAV is considered as a non-integrating vector and this can be a limit to their long-term expression. However, random integration events were observed with a low frequency of $10^{-4}-10^{-5}$ with no preference for specific genomic loci $(17,18)$. A recent study of gene therapy, in animal model, has shown that fragments of the sequence of vector, cDNA or regulatory elements, were integrated in the genome of the cells of the animals treated with AAV vectors. While AAV integration was observed, the animals had no evidence of malignancy (19). The authors report that integration may be essential for longterm expression of a protein, but it could become an intolerable risk of developing cancer (20). The hypothesis that AAVs are linked with tumour is controversy, since some studies report that infection with AAVs has an oncogenic effect in the animal model and others suggest a tumour suppressive role (21-25).

Another drawback issue is the pre-existing antibodies against the capsid protein that can hinder the use of AAV by preventing liver transduction. About $40 \%$ of the general population has a pre-existing immunity for some AAV serotypes that pose a critical challenge for the translation of gene therapies (26). New alternative strategies are emerging to try to eradicate these antibodies as well as the plasma exchange or the administration of immunosuppressive drugs.

AAV vectors have been shown to be effective in improving the bleeding phenotype by maintaining sustained levels of FIX expression in preclinical studies in animal model of haemophilia B conducted in the late $1990 \mathrm{~s}(8,11,13,15,27,28)$. The first patients were enrolled in a gene therapy trial in 2006 (29). A recombinant AAV vector serotype 2 (rAAV-2) expressing FIX was delivered in the portal vein which was considered the optimal delivery of the therapeutic gene directly into the liver, being the natural 
site for FIX synthesis. Therapeutic levels of FIX, $12 \%$ in one patient and $4 \%$ in the other patient, was documented in the group of patients treated with the highest dose $\left(2 \times 10^{12} \mathrm{vg} / \mathrm{kg}\right)$ of vector, and duration of expression at therapeutic levels was limited to a period of eight weeks (29). A transient asymptomatic elevation of liver transaminases was observed in conjunction with the decrease in FIX level, probably due to an immune response to the AAV capsid (30).

\section{Haemophilia B clinical trails}

The first evidence that gene therapy could change the cure in haemophilic patients was obtained in 2011 by Dr. Nathwani and Prof. Tuddenham (31). A self-complementary AAV serotype 2 pseudo typed with a capsid of serotype 8 (scAAV2/8-LP1hFIXco) was chosen for its notable liver tropism and relatively low rate of neutralizing antibodies to the vector capsid, since AAV8 wild-type virus rarely infects humans $(32,33)$. To ameliorate the expression of the molecule, F9 cDNA was codon-optimized and transcriptional control elements was modified. Six patients with severe haemophilia B were infused with a low $\left(2 \times 10^{11} \mathrm{vg} / \mathrm{kg}\right)$, intermediate $\left(6 \times 10^{11} \mathrm{vg} / \mathrm{kg}\right)$ and high dose $\left(2 \times 10^{12} \mathrm{vg} / \mathrm{kg}\right)$ of the vector. FIX activity level was observed in all infused patients, and the highest FIX levels was observed in the high dose group with a range from 8 to $12 \%$ of normal levels. A significant adverse event encountered during the trial was represented by asymptomatic transient elevation of serum liver enzymes in two of the six participants treated with the high dose of vector, which resolved with a course of steroid therapy (31). Evidence of durability of gene therapy was reported in 2014. Six participants enrolled in the initial phase 1 trial showed a range of FIX activity from $1,4 \%$ to $7,21 \%$, as well as four additional patients receiving the high dose of vector $\left(2 \times 10^{12} \mathrm{vg} / \mathrm{kg}\right)$ exhibited a range of activity from $2,8 \%$ to $6,6 \%$ over a median period of 3 years (34). These patients have been followed and monitored for a period of almost ten years showing a stable FIX activity level between $2.0 \%$ and $5.0 \%$ (35). In subsequent years, alternative AAV vector serotypes have been employed to circumvent possible pre-existing immunity effects, and different vector dosages were infused to achieve the best transduction. DTX101 is an AAVrh10 vector containing a codonoptimized wild-type F9 cDNA (Dimension Therapeutics). Patients were infused intravenously with two different doses $\left(1.6 \times 10^{12} \mathrm{vg} / \mathrm{kg}\right.$ and $5 \times 10^{12}$ $\mathrm{vg} / \mathrm{kg}$ ). After a follow-up period of 52 weeks, the level stabilised at 3-4\%, and recently, the company decided to discontinue this clinical trial because the Phase 1/2 open-label clinical study did not demonstrate an ability to achieve a minimum target product profile for continued development or future commercialization $(36,37)$.

UniQure Biopharma has a phase 1/2 study for haemophilia B with an AAV5 vector containing wildtype F9 cDNA (AMT-060) at doses of $5 \times 10^{12}$ to $2 \times 10^{13} \mathrm{vg} / \mathrm{kg}$. Treatment with AMT-060 resulted in a stable FIX activity levels, with a mean yearly FIX levels at $6.0 \%$ in the low dose group across 4 years and $7.9 \%$ in the high dose group at 3.5 years. A single infusion of AMT-060 results in a reduction in the mean annualized bleeding rate (ABR) of $88 \%$ and $83 \%$, and also the consumption of FIX concentrates decreased $96 \%$ and $93 \%$ compared to the pretreatment period $(38,39)$. A transient increase in alanine aminotransferase level occurred in the first 3.5 months post AMT-060 infusion in three subjects; all three subjects received steroid therapy and none experienced appreciable FIX activity loss.

To improve vector performance and increase FIX expression levels, the gain-of-function mutation known as Padua (R338L) has been inserted into the F9 cDNA. This naturally occurring mutation in the FIX catalytic domain increases FIX activity levels by 5 to 10 times compared with the wild type FIX (40).

BAX335, an AAV vector serotype 8 (AskBio9001, BAX335) containing F9 cDNA with FIX-Padua variant with liver specific promoter/enhancer ele- 
ments. During phase $1 / 2$, eight patients have been treated with three ascending doses of vector. Median peak FIX levels were $3.5 \%, 12.0 \%$, and $45.0 \%$ in patients managed with the low $\left(2 \times 10^{11} \mathrm{vg} / \mathrm{kg}\right)$, intermediate $\left(1 \times 10^{12} \mathrm{vg} / \mathrm{kg}\right)$ and high $\left(3 \times 10^{12} \mathrm{vg} / \mathrm{kg}\right)$ dose, respectively (41). Only two out of all treated subjects have sustained FIX expression for a year, and one subject, treated with the intermediate dose, continues to have a FIX level of $20 \%$ at follow-up of nearly 2.5 years (41). A transient elevation in transaminase level has been reported in two patients.

The clinical trial supported by Spark Therapeutics in collaboration with Pfizer, conducted in haemophilia B patients, with a hepatotropic AAV vector expressing the FIX Padua variant (fidanacogene elaparvovec, previously SPK-9001) showed to achieve a relevant improvement of FIX activity levels. Data on the first ten patients who received the infusion of SPK-9001 showed a mean sustained FIX activity level of $33.7 \pm 18.5 \%$ (14.3-76.8\%) over a period of 52 weeks, resulting in complete cessation of the prophylaxis in eight of ten patients (42). There were no serious adverse events involving the development of FIX inhibitor or thrombosis. The data on fifteen patients infused with fidanacogene elaparvovec with a follow-up of more than 1 year were reported during the American Society of Hematology (ASH) meeting 2019. The mean of FIX activity levels was $22.9 \% \pm 9.9 \%$ after one year as measured by one-stage assay. Three patients were treated with steroids for an asymptomatic increase of alanine aminotransferases (43).

UniQure Biopharma has later developed another AAV5 viral vector carrying a gene cassette containing F9 cDNA with FIX-Padua variant to improve the expression level of FIX protein (AMT-061). Patients received one intravenous infusion at dose of $2 \times 1013 \mathrm{vg} / \mathrm{kg}$. After AMT-061 treatment, FIX activity increased rapidly to a mean of $31 \%$ at six weeks. The FIX activity reached the mean level of $45 \%$ over 36 weeks demonstrating a reduction of ABR of $100 \%$. There were no clinically significant elevations in liver enzymes and no patients required steroids therapy (44).

UCL Royal Free Hospital and Freeline Therapeutics is performing a phase $1 / 2$ clinical trial in haemophilia B patients with FLT180a (AAV2/S3HLP2-Ti-FIXco), a next generation vector that consists of single strand AAV in which a FIX codon optimised with the FIX-Padua under the control of a new small liver-specific (HLP2) promoter and encapsulated in a novel synthetic capsid (AAV/S3) which significantly improve the transduction of human hepatocytes (45). Two patients have been treated with low dose of vector $\left(4.5 \times 10^{11} \mathrm{vg} / \mathrm{kg}\right)$. These patients received prophylactic steroids treatment between week 4 and week 12 to decrease the risk of transaminitis. Steady state FIX:C levels were $42.5 \pm 6 \%$ at 52 and 44 weeks of follow- up. Prophylaxis with FIX concentrates was stopped within the first week post FLT180a administration (45).

A next generation vector, TAK-748/SHP648 (Baxalta/Takeda), is in development and includes three cis-regulatory elements (CRM8) to increase the strength of the liver-specific transthyretin promoter driving the expression of a human FIX transgene. The dose-response relationship has been explored in FIX knockout mice and monkeys (46). These experiments showed that the treatment with TAK748/SHP648 was well tolerated and efficacious resulting in a dose-dependent plasma FIX activity. Phase $1 / 2$ is ongoing to evaluate the safety with a dose escalation study (EudraCT2018-004024-11).

The studies of gene therapy in haemophilia B have demonstrated a long-term expression of FIX transgene for several years following administration of a single dose of the AAV vectors, even though the AAV genome is retained in the liver in an episomal form and is supposed to lose its expression over time. Recently, a study in dogs with haemophilia A reported long-term expression of transgene protein between 2.2 and 10.1 years. Integration events in the liver cells of multiple dogs were shown without any evidence of tumorigenesis (19). This may suggest that integration events could occur that 
justify the long-term expression of FIX observed in several clinical trials. Therefore, a long-term follow-up study is required to evaluate the safety of gene therapy trials in human.

In the majority of clinical trials, an increase in transaminases was reported. This important adverse event was often observed in association with a transitory decline in FIX levels. The pathophysiological mechanism for the liver toxicity remains unclear. One explanation could be that the liver toxicity was likely caused by a capsid-specific cytotoxic $\mathrm{T}$ cell responses against the vector-transduced cells (47). The elevation of transaminases generally resolved with a short round of steroid therapy. However, unfortunately, steroid therapy is not successful in all patients, because the immunosuppressive action of this drug does not stop capsid-specific $\mathrm{T}$ cell responses (47) and to date, duration, optimal dose and time to start this treatment is not clear yet.

\section{Haemophilia A clinical trails}

To improve FVIII expression, modifications of the human F8 cDNA has been performed: a codon-optimized human FVIII cDNA has been designed, the $\mathrm{B}$ domain has been replaced, and also the liver-specific promoter has been added. This remodelling of F8 cDNA determined an increased FVIII expression in in-vivo gene transfer conducted in mice and non-human primates (48-50).

In 2017, a single peripheral infusion of an AAV5 vector containing a codon-optimized B-domain deleted F8 cDNA, in nine men with severe haemophilia A showed a sustained normalization of FVIII activity level. The changes in the vector and the F8 cDNA resulted in successful gene transfer, despite the large size of the coding region. A value of $3 \%$ or less of FVIII activity was detected in patients treated with low and intermediate dose of vector $\left(6 \times 10^{12} \mathrm{vg} / \mathrm{kg}\right.$ and $\left.2 \times 10^{13} \mathrm{vg} / \mathrm{kg}\right)$. In six patients administered with high dose $\left(6 \times 10^{13} \mathrm{vg} / \mathrm{kg}\right)$, the FVIII activity level increased to a normal value $(>50 \%)$ (51). Data from the phase $1 / 2$ clinical trial in hae- mophilia A using Valrox (valoctocogene roxaparvovec; BMN 270; BioMarin Pharmaceutical) at two different doses of $6 \times 10^{13} \mathrm{vg} / \mathrm{kg}$ and $4 \times 10^{13} \mathrm{vg} / \mathrm{kg}$ showed that the mean FVIII activity level was $64 \%$ with the highest dose of vector and $21 \%$ with the other dosage measured with the chromogenic assay one year after infusion. At the end of the second year, FVIII activity levels in the high dose cohort measured by the chromogenic assay were about $36.4 \%$ on average. A durable expression was also shown in the cohort of patients treated with a lower dosage of vector; the mean FVIII activity level was 15\%. The expression FVIII appeared to reach a plateau in the third year with a mean level of FVIII of $32.7 \%$ in the high dose cohort of patients (52). The efficacy was evaluated considering the ABR that resulted to be declined from pre-treatment mean by $96 \%$ at year three in $6 \times 10^{13} \mathrm{vg} / \mathrm{kg}$ and $92 \%$ at year two in $4 \times 10^{13} \mathrm{vg} / \mathrm{kg}$ (52). Considering the safety profile, Valrox was well tolerated, eight participants had increased values of alanine aminotransferases, which resolved without sequelae. No patient developed antibodies against FVIII. Valrox was the first gene therapy for the treatment of patients with haemophilia A that has undergone FDA priority review. Unfortunately, the FDA rejects gene therapy for haemophilia BIoMarine, asking for more data. The FDA has recommended BioMarin to complete the Phase III study and to submit two-year safety and efficacy follow-up data on the 134 patients.

A bioengineered AAV capsid (SPK-8011) expressing B-domain deleted FVIII under the control of a liver-specific promoter at three different doses $\left(5 \times 10^{11} \mathrm{vg} / \mathrm{kg}, 1 \times 10^{12} \mathrm{vg} / \mathrm{kg}\right.$ or $\left.2 \times 10^{12} \mathrm{vg} / \mathrm{kg}\right)$ has been administered in twelve patients with haemophilia A (Spark Therapeutics/Roche) (53-54). A mean FVIII level of $13 \%$ and $15 \%$ was observed in patients treated with low and intermediate dose of the vector. While, five out of seven subjects who received a high dose of the vector had a FVIII level of $30 \%$ at 12 weeks post-infusion, additionally, these patients received a course of steroid therapy, started at 6-11 weeks post vector infusion (54). Two pa- 
tients experienced an elevation of transaminase associated with an immune response to AAV capsid. Starting steroids normalized the level of liver enzymes, however, these two patients also showed a decrease in FVIII activity level $(<6 \%)$. A good efficacy profile was observed with a $97 \%$ reduction in ABR. No evidence of inhibitor formation was reported (54).

A phase 1/2 clinical trial supported by Sangamo Therapeutics was conducted in patients with haemophilia A treated with a rAAV vector serotype 6 carrying a B domain deleted F8 cDNA (SB-525). Eleven patients received a single infusion of SB525 across four ascending doses of vector $\left(9 \times 10^{11}\right.$ $\mathrm{vg} / \mathrm{kg}, 2 \times 10^{12} \mathrm{vg} / \mathrm{kg}, 1 \times 10^{13} \mathrm{vg} / \mathrm{kg}$ or $\left.3 \times 10^{13} \mathrm{vg} / \mathrm{kg}\right)$. Patients in the high dose cohort showed FVIII activity levels within the normal range at 28 weeks post infusion, resulting in complete cessation of prophylaxis. No alanine aminotransferase elevation was observed in the three cohort of patients treated with low or intermediate dose of vector. While in the high dose cohort, three patients experienced a transient liver enzymes elevation managed a course of steroid, but none were associated with a loss of FVIII activity (55).

Preliminary data has been reported from the phase $1 / 2$ clinical trials in haemophilia $\mathrm{A}$, in which one patient with severe haemophilia A received a dose of $6 \times 10^{11}$ and the subsequent two patients received a dose of $2 \times 10^{12} \mathrm{vg} / \mathrm{kg}$ of AAV8-HLP-hFVIII-V3 vector (University College London). FVIII activity levels more than $>5 \%$ have been achieved which remained stable over a period of 47 weeks (56). Aminotransferase elevation was observed in two patients treated with steroid therapy within 48 hours of the onset of transaminitis with no loss of transgene expression (56).

A non-replicating AAV vector, based on the serotype hu37, containing a B domain deleted F8 cDNA under the control of a liver-specific promoter/enhancer (BAY 2599023) has been designed by Bayer. AAVhu37 capsid has been selected for its ef- ficient liver-directed gene transfer, favourable biodistribution and durable expression of FVIII (57). Preliminary data from first patients enrolled in the phase $1 / 2$ clinical trials showed that AAVhu37 at a dose of $0.5 \times 10^{13} \mathrm{vg} / \mathrm{kg}$ determined a stable FVIII expression at 15 weeks. A value of $5 \%$ and $15 \%$ was measured post single infusion in the first two patients. No elevation of liver enzyme levels has been experienced and steroid was not used in either patients (57).

An alternative AAV vector for gene transfer in patients with haemophilia A with a liver-specific transthyretin promoter to guide the expression of codon optimized human B-domain deleted FVIII (SHP654/TAK-754/BAX888;Baxalta/Takeda) has been shown to be effective in animal models (58). Recently, Phase 1/2 Study of the safety and dose escalation of BAX 888 started with recruitment of patients. A phase $1 / 2$ study for the treatment of haemophilia A patients with inhibitors is ongoing. Spark Therapeutics has developed a modified AAV vector (SPK-8016) that carries a bioengineered gene encoding anti-FVIII inhibitors whose protein product can suppress FVIII inhibitors (59). The first part will evaluate the safety, efficacy and tolerability of SPK-8016 in adult males with clinically severe hemophilia A and no measurable inhibitors against FVIII.

The data obtained from this first part will inform the study design and dosage selection for second part in patients with FVIII inhibitors. The first data are expected during the first half of 2020 .

AMT-180 is being developed by uniQure as a gene therapy candidate for the treatment of haemophilia A patients who have developed FVIII inhibitors. This is a special viral AAV5 vector to deliver two modified versions of the FIX cDNA with four amino acid substitutions previously described (60). These FIX variants showed cofactor-independent activity which are capable of promoting coagulation in the absence of FVIII both in vivo and in vitro. Experiments in haemophilic mice and also in non- 
human primates have demonstrated a restoration of coagulation without thrombotic events (61).

The results of these trials confirm the efficiency and durability of AAV-mediated gene transfer following systemic administration of the vector. An asymptomatic rise in liver enzymes has been observed in treated patients and resolved with a course of oral steroid therapy. Concurrent with the onset of this adverse event, a decline in FVIII activity levels has been observed. Furthermore, there have been no additional reports of other serious adverse events, such as inhibitors development, in any of the reported trials.

\section{Conclusions}

Gene therapy is rapidly growing as a therapeutic reality for an increased number of patients with a wide range of diseases. In the last few years, clinical trials in gene therapy, for both haemophilia A and B, have been developed showing great efficacy and more durability, almost ten years for haemophilia B and three-four years for haemophilia A until now.

The severe phenotype of the haemophilia A and B patients has been converted to mild or even normal by gene therapy, which is becoming an exciting choice in the field of haemophilia treatment. Therefore, the effectiveness of gene therapy, accelerated more critically by scientific progress and clinical successes, justifies continued optimism and increasing efforts toward making these therapies the future of haemophilia management. Although, there are still some critical issues that need to be addressed as the increase in liver enzymes, the safety profile of different AAV serotypes, the effect of the vector manufacturing process, and also the potential genotoxicity derived from integrating gene delivery vectors.

Another relevant question, recently risen, is the discrepancy in FVIII and FIX activity assays. Several gene therapy clinical trials reported some differences in the FIX activity measurement using FIX Padua variant transgene product and recombinant human FIX-Padua when tested with different onestage and chromogenic assays (62-64). Moreover, Rangarajan and colleagues in 2017 reported that the FVIII activity levels measured by one stage clotting assay were approximately 1.65 times as high as the FVIII levels determined by the chromogenic assay (51). The heterogeneity of the data obtained with the different clotting assays makes difficult to compare the results between different clinical studies. A further issue concerns the availability of assays for the detection of pre-existing immunogenicity against different AAV serotypes. The International Society on Thrombosis and Haemostasis (ISTH) Scientific and Standardization Subcommittee (SSC) on Factor VIII, Factor IX and Rare Coagulation Disorders with specific working groups should optimise and standardise assays to measure transgenic expression and to detect the presence of pre-existing immunogenicity against the AAVs.

In conclusion, new trials are emerging with the use of powerful and flexible vehicles such as lentiviruses which shown a high efficiency of gene transfer and a capacity for stable transgene integration in the genome of target cells (65). Finally, genome editing technologies are evolving very rapidly. Recently, one of the most used genome editing tool, CRISPR/CAS9, has been used to mediate the insertion of human F9 and F8 in mice and non-human primates achieving therapeutic levels of these coagulant proteins (66-68). These approaches could also offer a precise tool for correcting the genome and can overcome many of the drawbacks of strategies that rely on viral vectors. Future research will shed more light on these questions.

\section{Conflict of interests}

IG has no competing interests to declare. FP has received honoraria for participating as a speaker at satellite symposia organized by Bioverativ, Grifols, Roche, Sanofi, Sobi, Spark and Takeda. She also reports participation on the advisory boards of Sanofi and Sobi. 


\section{References}

1. Blaese RM, Culver KW, Miller AD, Carter CS, Fleisher T, Clerici M, Shearer G, Chang L, Chiang Y, Tolstoshev P, Greenblatt JJ, Rosenberg SA, Klein H, Berger M, Mullen CA, Ramsey WJ, Muul L, Morgan RA, Anderson WF. T lymphocyte-directed gene therapy for ADA- SCID: initial trial results after 4 years. Science 1995;270(5235):475-80.

2. Peyvandi F, Garagiola I, Young G. The past and future of haemophilia: diagnosis, treatments, and its complications. Lancet 2016;388(10040):187-97.

3. Li C, Samulski RJ. Engineering adeno-associated virus vectors for gene therapy. Nat Rev Genet. 2020;21(4):255-72.

4. Raper SE, Chirmule N, Lee FS, Wivel NA, Bagg A, Gao GP, Wilson JM, Batshaw ML. Fatal systemic inflammatory response syndrome in a ornithine transcarbamylase deficient patient following adenoviral gene transfer. Mol Genet Metab. 2003;80(12):148-58

5. Hacein-Bey-Abina S, von Kalle C, Schmidt M, Le Deist F, Wulffraat N, McIntyre E, Radford I, Villeval JL, Fraser CC, Cavazzana-Calvo M, Fischer A. A serious adverse event after successful gene therapy for X-linked severe combined immunodeficiency. N Engl J Med 2003;348(3):255-6

6. Scott CT, DeFrancesco L. Gene therapy's out-of-body experience. Nat Biotechnol 2016;34(6):600-7

7. Qiu X, Lu D, Zhou J, Wang J, Yang J, Meng P, Hsueh JL. Implantation of autologous skin fibroblast genetically modified to secrete clotting factor IX partially corrects the hemorrhagic tendencies in two hemophilia B patients. Chin Med J (Engl). 1996;109(11):832-9.

8. Herzog RW, Hagstrom JN, Kung SH, Tai SJ, Wilson JM, Fisher KJ, High KA. Stable gene transfer and expression of human blood coagulation factor IX after intramuscular injection of recombinant adeno-associated virus. Proc Natl Acad Sci USA 1997;94(11):5804-9.

9. Wang L, Takabe K, Bidlingmaier SM, Ill CR, Verma IM. Sustained correction of bleeding disorder in hemophilia B mice by gene therapy. Proc Natl Acad Sci USA 1999;96(7):3906-10.

10. Chao H, Mao L, Bruce AT, Walsh CE. Sustained expression of human factor VIII in mice using a parvovirus-based vector. Blood 2000;95(5):1594-9.

11. Mount JD, Herzog RW, Tillson DM, Goodman SA, Robinson N, McCleland ML, Bellinger D, Nichols TC, Arruda VR, Lothrop CD Jr, High KA. Sustained phenotypic correction of hemophilia B dogs with a factor IX null mutation by liver directed gene therapy. Blood 2002;99(8):2670-6.

12. Chao H, Sun L, Bruce A, Xiao X, Walsh CE. Expression of human factor VIII by splicing between dimerized AAV vectors. Mol Ther 2002;5(6):716-22.

13. Nathwani AC, Gray JT, Ng CY, Zhou J, Spence Y, Waddington SN, Tuddenham EG, Kemball-Cook G, McIntosh J, Boon-Spijker M, Mertens K, Davidoff AM.Self-complementary adenoassociated virus vectors containing a novel liver-specific human factor IX expression cassette enable highly efficient transduction of murine and nonhuman primate liver. Blood 2006;107(7): 2653-61.

14. Sarkar R, Mucci M, Addya S, Tetreault R, Bellinger DA, Nichols TC, Kazazian HH Jr. Long-term efficacy of adeno-associated virus serotypes 8 and 9 in hemophilia A dogs and mice.
Hum Gene Ther 2006;17(4):427-439.

15. Nathwani AC, Gray JT, McIntosh J, Ng CY, Zhou J, Spence Y, Cochrane M, Gray E, Tuddenham EG, Davidoff AM. Safe and efficient transduction of the liver after peripheral vein infusion of self-complementary AAV vector results in stable therapeutic expression of human FIX in nonhuman primates. Blood 2007;109(4):1414-21.

16. La Bella T, Imbeaud S, Peneau C, Mami I, Datta S, Bayard Q, Caruso S, Hirsch TZ, Calderaro J, Morcrette G, Guettier C, Paradis V, Amaddeo G, Laurent A, Possenti L, Chiche L, BioulacSage P, Blanc JF, Letouze E, Nault JC, Zucman-Rossi J. Adenoassociated virus in the liver: natural history and consequences in tumour development. Gut. 2020;69(4):737-47.

17. Kaufmann KB, Büning H, Galy A, Schambach A, Grez M. Gene therapy on the move. EMBO Mol Med 2013;5(11):1642-61.

18. Colella P, Ronzitti G, Mingozzi F. Emerging Issues in AAVMediated In Vivo Gene Therapy. Mol Ther Methods Clin Dev 2017;8:87-104.

19. Nguyen GN, Everett JK, Raymond H, Kafle S, Merricks EP, Kazazian HH, Nichols TC, Bushman FD, Sabatino DE. LongTerm AAV-Mediated Factor VIII Expression in Nine Hemophilia A Dogs: A 10 Year Follow-up Analysis on Durability, Safety and Vector Integration. Blood 2019;134 (Suppl. 1):611.

20. Kaiser J. How safe is a popular gene therapy vector? Science 2020;367(6474):131.

21. Donsante A, Miller DG, Li Y, Vogler C, Brunt EM, Russell DW, Sands MS. AAV vector integration sites in mouse hepatocellular carcinoma. Science 2007;317(5837):477.

22. Chandler RJ, LaFave MC, Varshney GK, Trivedi NS, CarrilloCarrasco N, Senac JS, Wu W, Hoffmann V, Elkahloun AG, Burgess SM, Venditti CP. Vector design influences hepatic genotoxicity after adeno-associated virus gene therapy. J Clin Invest 2015;125(2):870-80.

23. Wang PR, Xu M, Toffanin S, Li Y, Llovet JM, Russell DW. Induction of hepatocellular carcinoma by in vivo gene targeting. Proc Natl Acad Sci USA 2012;109(28):11264-9.

24. Hermonat PL, Plott RT, Santin AD, Parham GP, Flick JT. Adeno-associated virus Rep78 inhibits oncogenic transformation of primary human keratinocytes by a human papillomavirus type 16-ras chimeric. Gynecol Oncol 1997;66(3):487-94.

25. Liu T, Cong M, Wang P, Jia J, Liu Y, Hermonat PL, You H Adeno-associated virus Rep78 protein inhibits Hepatitis B virus replication through regulation of the HBV core promoter. Biochem Biophys Res Commun 2009;385(1):106-11.

26. Hurlbut GD, Ziegler RJ, Nietupski JB, Foley JW, Woodworth LA, Meyers E, Bercury SD, Pande NN, Souza DW, Bree MP, Lukason MJ, Marshall J, Cheng SH, Scheule RK. Preexisting immunity and low expression in primates highlight translational challenges for liver directed AAV8-mediated gene therapy. Mol Ther 2010;18(11):1983-94.

27. Herzog RW, Yang EY, Couto LB, Hagstrom JN, Elwell D, Fields PA, Burton M, Bellinger DA, Read MS, Brinkhous KM, Podsakoff GM, Nichols TC, Kurtzman GJ, High KA. Long-term correction of canine hemophilia B by gene transfer of blood coagulation factor IX mediated by adeno-associated viral vector. Nat Med 1999;5(1):56-63.

28. Snyder RO, Miao C, Meuse L, Tubb J, Donahue BA, Lin HF, Stafford DW, Patel S, Thompson AR, Nichols T, Read MS, Bellinger DA, Brinkhous KM, Kay MA.Correction of hemophilia 
$\mathrm{B}$ in canine and murine models using recombinant adeno-associated viral vectors. Nat Med 1999;5(1):64-70.

29. Manno CS, Pierce GF, Arruda VR, Glader B, Ragni M, Rasko JJ, Ozelo MC, Hoots K, Blatt P, Konkle B, Dake M, Kaye R, Razavi M, Zajko A, Zehnder J, Rustagi PK, Nakai H, Chew A, Leonard D, Wright JF, Lessard RR, Sommer JM, Tigges M, Sabatino D, Luk A, Jiang H, Mingozzi F, Couto L, Ertl HC, High KA, Kay MA. Successful transduction of liver in hemophilia by AAV-Factor IX and limitations imposed by the host immune response. Nat Med. 2006;12(3): 342-7.

30. Mingozzi F, Maus MV, Hui DJ, Sabatino DE, Murphy SL, Rasko JE, Ragni MV, Manno CS, Sommer J, Jiang H, Pierce GF, Ertl HC, High KA. CD8(+) T-cell responses to adeno associated virus capsid in humans. Nat Med 2007;13(4):419-22.

31. Nathwani AC, Tuddenham EG, Rangarajan S, et al. Adenovirus-associated virus vector-mediated gene transfer in hemophilia B. N Engl J Med. 2011;365:2357-2365.

32. Boutin S, Monteilhet V, Veron P, Leborgne C, Benveniste O, Montus MF, Masurier C. Prevalence of serum IgG and neutralizing factors against adeno-associated virus (AAV) types 1, 2, 5, 6,8 , and 9 in the healthy population: implications for gene therapy using AAV vectors. Hum Gene Ther. 2010;21(6):704-12.

33. Perocheau DP, Cunningham S, Lee J, Antinao Diaz J, Waddington SN, Gilmour K, Eaglestone S, Lisowski L, Thrasher AJ, Alexander IE, Gissen P, Baruteau J. Age-Related Seroprevalence of Antibodies Against AAV-LK03 in a UK Population Cohort. Hum Gene Ther. 2019;30(1):79-87.

34. Nathwani AC, Reiss UM, Tuddenham EG, Rosales C, Chowdary P, McIntosh J, Della Peruta M, Lheriteau E, Patel N, Raj D, Riddell A, Pie J, Rangarajan S, Bevan D, Recht M, Shen YM, Halka KG, Basner-Tschakarjan E, Mingozzi F, High KA, Allay J, Kay MA, Ng CY, Zhou J, Cancio M, Morton CL, Gray JT, Srivastava D, Nienhuis AW, Davidoff AM. Long-term safety and efficacy of factor IX gene therapy in hemophilia B. N Engl J Med 2014;371(21):1994-2004.

35. Nathwani A, Reiss U, Tuddenham E, Chowdary P, McIntosh J, Riddell A, Pie J, Mahlangu JN, Recht M, Shen Y, Halka KG, Meagher MM, Nienhuis AW, Davidoff AM, Mangles S, Morton CL, Junfang Z, Radulescu VC. Adeno-Associated Mediated Gene Transfer for Hemophilia B: 8 Year Follow up and Impact of Removing "Empty Viral Particles" on Safety and Efficacy of Gene Transfer. Blood 2018;132 (Suppl.1): 491.

36. https://globenewswire.com/news-release/2017/01/31/912410/0 /en/Dimension-Announces-Interim-Topline-Results-from-Ongoing-Phase-1-2-Clinical-Program-for-DTX101-Dimension-sLead-AAV-Product-Candidate-in-Development-for-Adult-Pa$\underline{\text { tients-with-Moderat.html. }}$

37. https://hemophilianewstoday.com/2017/05/15/dimension-therapeutics-to-end-hemophilia-b-gene-therapy-dtx101-development/.

38. Miesbach W, Meijer K, Coppens M, Kampmann P, Klamroth R, Schutgens R, Castaman G, Seifried E, Schwaeble J, Bönig H, Sawyer EK, Leebeek FWG. Stable FIX Expression and Durable Reductions in Bleeding and Factor IX Consumption for up to 4 Years Following AMT-060 Gene Therapy in Adults with Severe or Moderate-Severe Hemophilia B. Blood 2019;134 (Suppl.1): 2059.

39. Leebeek FW, Meijer K, Coppens M, Kampmann P, Klamroth R, Schutgens R, Castaman G, Seifried E, Schwable J, Bonig H,
Sawyer EK, Miesbach W. Stable FIX expression and durable reductions in bleeding and Factor IX consumption for up to 4 years following AMT-060 gene therapy in adults with severe or moderate hemophilia B. Haemophilia 2020;26(S2):78.

40. Simioni P, Tormene D, Tognin G, Gavasso S, Bulato C, Iacobelli NP, Finn JD, Spiezia L, Radu C, Arruda VR. X-linked thrombophilia with a mutant factor IX (factor IX Padua). N Engl J Med 2009;361(17):1671-5.

41. Chapin J, Rottensteiner H, Scheiflinger F, Monahan PE. An Analysis of bleeding rates and Factor IX consumption in the Phase I/II BAX 335 gene therapy trial in subjects with hemophilia B. Res Pract Thromb Haemost. 2017;1(Suppl. 1):144.

42. George LA, Sullivan SK, Giermasz A, Rasko JEJ, SamelsonJones BJ, Ducore J, Cuker A, Sullivan LM, Majumdar S, Teitel J, McGuinn CE, Ragni MV, Luk AY, Hui D, Wright JF, Chen Y, Liu Y, Wachtel K, Winters A, Tiefenbacher S, Arruda VR, van der Loo JCM, Zelenaia O, Takefman D, Carr ME, Couto LB, Anguela XM, High KA. Hemophilia B Gene Therapy with a High-Specific-Activity Factor IX Variant. N Engl J Med 2017;377(23):2215-27.

43. Sullivan SK, Rasko JEJ, Giermasz A, Samelson-Jones BJ, Ducore JM, Teitel JM, McGuinn CE, Runowski AR, Wright F, Anguela XM, High KA, Rybin D, Murphy JE, Rupon J. Efficacy and Safety in 15 Hemophilia B Patients Treated with the AAV Gene Therapy Vector Fidanacogene Elaparvovec and Followed for at Least 1 Year. Blood 2019;134(Suppl.1):3347.

44. Pipe SW, Miesbach W, Giermasz A, Castaman G, Key NS, Lattimore S, Leebeek FW, Recht M, Gomez E, Long A, Gut R, Von Drygalski A. One year data from a Phase 2B trial of AMT-061 (AAV5-PADUA HFIX variant), an enhanced vector for gene transfer in adults with severe or moderate-severe hemophilia B. Haemophilia 2020;26(S2):25.

45. Chowdary P, Shapiro S, Davidoff AM, Reiss U, Alade R, PhD5*, Brooks G, Dane A, McIntosh J, Short G, Tuddenham E, Nathwani AC. Single intravenous infusion of FLT180a results in Factor IX activity levels of more than $40 \%$ and has the potential to provide a functional cure for patients with haemophilia B. Blood 2018;132(Suppl.1):631.

46. Weiller M, Schuster M, Coulibaly S, Sun K, Rottensteiner H,Chuah MK, VandenDriessche T, Scheiflinger F, Hoellrieg W. Nonclinical Pharmacology of TAK-748/SHP648 a Novel Factor IX (FIX) Gene Therapy Vector in Mice and Rhesus Monkeys. Res Pract Thromb Haemost 2019;3(Suppl. 1):92.

47. Ertl HCJ, High KA. Impact of AAV Capsid-Specific T-Cell Responses on Design and Outcome of Clinical Gene Transfer Trials with Recombinant Adeno-Associated Viral Vectors: An Evolving Controversy. Hum Gene Ther 2017;28(4):328-37.

48. Siner JI, Samelson-Jones BJ, Crudele JM, French RA, Lee BJ, Zhou S, Merricks E, Raymer R, Nichols TC, Camire RM, Arruda VR. Circumventing furin enhances factor VIII biological activity and ameliorates bleeding phenotypes in hemophilia models. JCI Insight 2016;1(16):e89371.

49. Siner JI, Iacobelli NP, Sabatino DE, Ivanciu L, Zhou S, Poncz M, Camire RM, Arruda VR. Minimal modification in the factor VIII B-domain sequence ameliorates the murine hemophilia A phenotype. Blood 2013;121(21):4396-4403.

50. McIntosh J, Lenting PJ, Rosales C, Lee D, Rabbanian S, Raj D, Patel N, Tuddenham EG, Christophe OD, McVey JH, Waddington S, Nienhuis AW, Gray JT, Fagone P, Mingozzi F, Zhou SZ, 
High KA, Cancio M, Ng CY, Zhou J, Morton CL, Davidoff AM, Nathwani AC. Therapeutic levels of FVIII following a single peripheral vein administration of rAAV vector encoding a novel human factor VIII variant. Blood 2013;121(17):3335-44.

51. Rangarajan S, Walsh L, Lester W, Perry D, Madan B, Laffan M, Yu H, Vettermann C, Pierce GF, Wong WY, Pasi KJ. AAV5Factor VIII Gene Transfer in Severe Hemophilia A. N Engl J Med 2017;377(26):2519-30.

52. https://investors.biomarin.com/2019-05-28-BioMarin-Provides-3-Years-of-Clinical-Data-from-Ongoing-Phase-1-2-Studyof-Valoctocogene-Roxaparvovec-Gene-Therapy-for-SevereHemophilia-A.

53. George LA, Ragni MV, Samelson-Jones BJ, Cuker A, Runoski AR, Cole G, Wright F, Chen Y, Hui DJ, Wachtel K, Takefman D, Couto LB, Reape KZ, Carr ME, Anguela XM, High KA. Spk-8011: Preliminary results from a Phase 1/2 dose escalation trial of an investigational AAV-Mediated gene therapy for hemophilia A. Blood 2017:130(Suppl. 1):604.

54. High KA, George LA, Eyster ME, Sullivan SK, Ragni MV, Croteau SE, Samelson-Jones BJ, Evans M, Joseney-Antoine M, Macdougall A, Kadosh J, Runoski AR, Campbell-Baird C, Douglas K, Tompkins S, Hait H, Couto LB, Bassiri AE, Valentino LA, Carr ME, Hui DJ, Wachtel K, Takefman D, Mingozzi F, Anguela XM, Reape KB, A Phase 1/2 Trial of Investigational Spk-8011 in Hemophilia a Demonstrates Durable Expression and Prevention of Bleeds. Blood 2018;132(Suppl.1):487.

55. Konkle B, Stine K, Visweshwar N, Harrington TJ, Leavitt AD, Giermasz A, Arkin S, Di Russo G, Snyder A, Woolfson A, Rouy D. Updated Follow-up of the Alta Study, a Phase 1/2, Open Label, Adaptive, Dose-Ranging Study to Assess the Safety and Tolerability of SB-525 Gene Therapy in Adult Patients with Severe Hemophilia A. Blood 2019;134(Suppl.1):2060.

56. Nathwani AC, Tuddenham E, Chowdary P, McIntosh J, Lee D, Rosales C, Phillips M, Pie J, Junfang Z, Meagher MM, Reiss U, Davidoff AM, Morton CL, Riddell A. GO-8: Preliminary Results of a Phase I/II Dose Escalation Trial of Gene Therapy for Haemophilia a Using a Novel Human Factor VIII Variant. Blood 2018;132(Suppl.1):489.

57. Pipe S, Becka M, Detering E, Vanevski K, Lissitchkov T. Firstin-human gene therapy study of AAVHU37 capsid vector technology in severe haemophilia A: safety and FVIII activity results. Res Pract Thromb Haemost. 2019;3(Suppl. 1):124.

58. Rajavel k, Ayash-Rashkovsky M, Tang Y, Gangadharan B, de la Rosa M, Ewenstein B. Co-Prevalence of Pre-Existing Immunity to Different Serotypes of Adeno-Associated Virus (AAV) in Adults with Hemophilia. Blood 2019;134(Suppl.1):3349.

59. Batty P, Lillicrap D. Advances and challenges for hemophilia gene therapy. Hum Mol Genet 2019;28(R1):R95-R101

60. Quade-Lyssy P, Abriss D, Milanov P, Ungerer C, Königs C,Seifried E, Schüttrumpf J. Next generation FIX muteins with FVIII-independent activity for alternative treatment of hemophilia A. J Thromb Haemost 2014;12(11):1861-73.

61. Liu YP, Zancanella V, Au B, Montenegro-Miranda P, de Haan M, Strijbis VJF, Bos MHA, Huber K, Schwable J, Seifried E, Konstantinova P, Van Deventer S. AAV5-mediated gene therapy for hemophilia A with a factor IX variant that functions independently of FVIII. Res Pract Thromb Haemost 2019;3(Suppl. 1):93.

62. Samelson-Jones BJ, Arruda VR. Protein-Engineered Coagulation Factors for Hemophilia Gene Therapy. Mol Ther Methods Clin Dev 2018;12:184-201.

63. Robinson M, George LA, Samelson-Jones BJ, Arruda VR, High KA, Carr ME, Tiefenbacher S, in the abstract entitle: Activity of a FIX-Padua Transgene Product in Commonly Used FIX:C One-Stage and Chromogenic Assay Systems Following PF06838435 (SPK-9001) Gene Delivery. Blood. 2018;132 (Suppl.1):2198.

64. Chowdary P, Shapiro S, Boyce S, Davidoff A, Reiss U, Alade R, Brooks G, Short G, Foley J, Hamid C, Riddell A, Tuddenham E, Nathwani A. FLT180a: Next generation AAV vector for haemophilia B - Long Term, Follow- up and In- depth Analysis of Transgenic FIX Using One- stage, Chromogenic and Global Assays. Res Pract Thromb Haemost 2019;3(Suppl. 1):307.

65. Milani M, Annoni A, Moalli F, Liu T, Cesana D, Calabria A, Bartolaccini S, Biffi M, Russo F, Visigalli I, Raimondi A, Patarroyo-White S, Drager D, Cristofori P, Ayuso E, Montini E, Peters R, Iannacone M, Cantore A, Naldini L, Phagocytosisshielded lentiviral vectors improve liver gene therapy in nonhuman primates. Sci Transl Med 2019;11(493):pii: eaav7325.

66. Carroll D. Genome editing: progress and challenges for medical applications. Genome Med. 2016;8(1):120.

67. Wang L, Yang Y, Breton CA, White J, Zhang J, Che Y, Saveliev A, McMenamin D, He Z, Latshaw C, Li M, Wilson JM. CRI$\mathrm{SPR} / \mathrm{Cas} 9-$ mediated in vivo gene targeting corrects hemostasis in newborn and adult factor IX-knockout mice. Blood 2019;133(26):2745-52.

68. Brooks A, Vo K, Wodziak D, Aeran R, Abe K, Mallari C, Guerrero V, Cheng C, Scharenberg A. Therapeutic Levels of FVIII Generated by CRISPR/Cas9- mediated in vivo genome editing in hemophilia A mice. Res Pract Thromb Haemost. 2019;3(Suppl. 1):105. 